\title{
Petrochemistry of granite and granophyres of the Ezhimala igneous complex, Kerala, India
}

\author{
N G K NAIR and M SANTOSH \\ Centre for Earth Science Studies, P.B. 2235. Trivandrum 695 010, India \\ MS received 2 September 1982; revised 22 December 1982
}

\begin{abstract}
Anorthosite-gabbro-granite-granophyre suite of rocks occurring in the Precambrian migmatitic gneiss of Cannanore district, Kerala and spatially related to the Bavali lineament. constitute the Ezhimala igneous complex (EIC). The granophyres exhibit typical cuneiform and radiating fringe-type intergrowths. Geochemistry indicates a tonalitic .... trondhjemitic to granitic composition of the residual magma. Petrochemical characters and lithologic association suggest that the EIC represents a complete differentiation sequence derived by strong fractionation and crystal cumulation of a parent basaltic magma which followed a tholeitic differentiation trend, with no significant crustal particination as implied by the low initial strontium isotope levels. Occurrence of the complex along the Bavali lineament, which is a major rift-zone, emphasises a rift-controlled magmatism in this part of the Indian shield
\end{abstract}

Keywords. Granite; granophyre; lineament; fractional crystallization; rift-controlled magmatism.

\section{Introduction}

Petrochemical studies on acid igneous rocks occurring in the Precambrian crystalline terrane of the Kerala region which forms the south-western part of the Indian shield, have been recently taken up (Santosh and Nair 1983) to decipher the tectonic environment of the rifted continental margin of India. The Ezhimala complex of Cannanore district, Kerala is of special interest, as rock types ranging from massive anorthosites through gabbros to granite and granophyres occur in spatial relation to a major fracture zone designated as the Bavali lineament (figure la).

The occurrences of the granophyre (Varadan and Venkataramana 1976) and rapakivi texture in the associated granite (Nair and Vidyadharan 1982) in the area were earlier reported. The Bavali lineament is considered to be a deep-seated rift-zone based on detailed petrochemical studies on the perpotassic pluton of Peralimala which occurs along this lineament (Nair and Santosh 1983).

\section{Geological setting}

The anorthosites of Perinthatta and Kadannappalli and the gabbro, granite and granophyres of Ezhimala, occurring in the Precambrian migmatitic gneisses, together constitute the Ezhimala complex, hereinafter referred to as the Ezhimala igneous complex (EIC). There is a pronounced compositional variation from massive anorthosite through gabbroic anorthosite and gabbro to the gabbro-granophyre massif of Ezhimala. Eventhough correlation of the EIC with Deccan Trap volcanism has been attempted (Varadan and Venkataramana 1976), consanguinous age of $678 \mathrm{~m} . \mathrm{y}$. is 


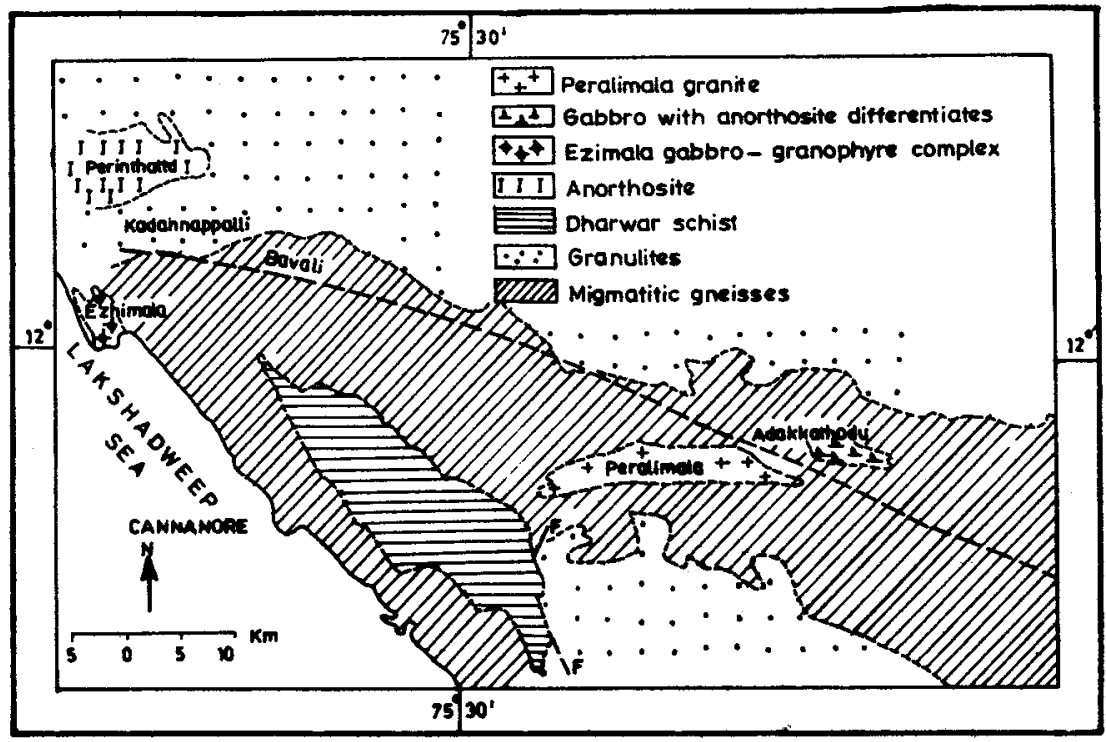

(a)

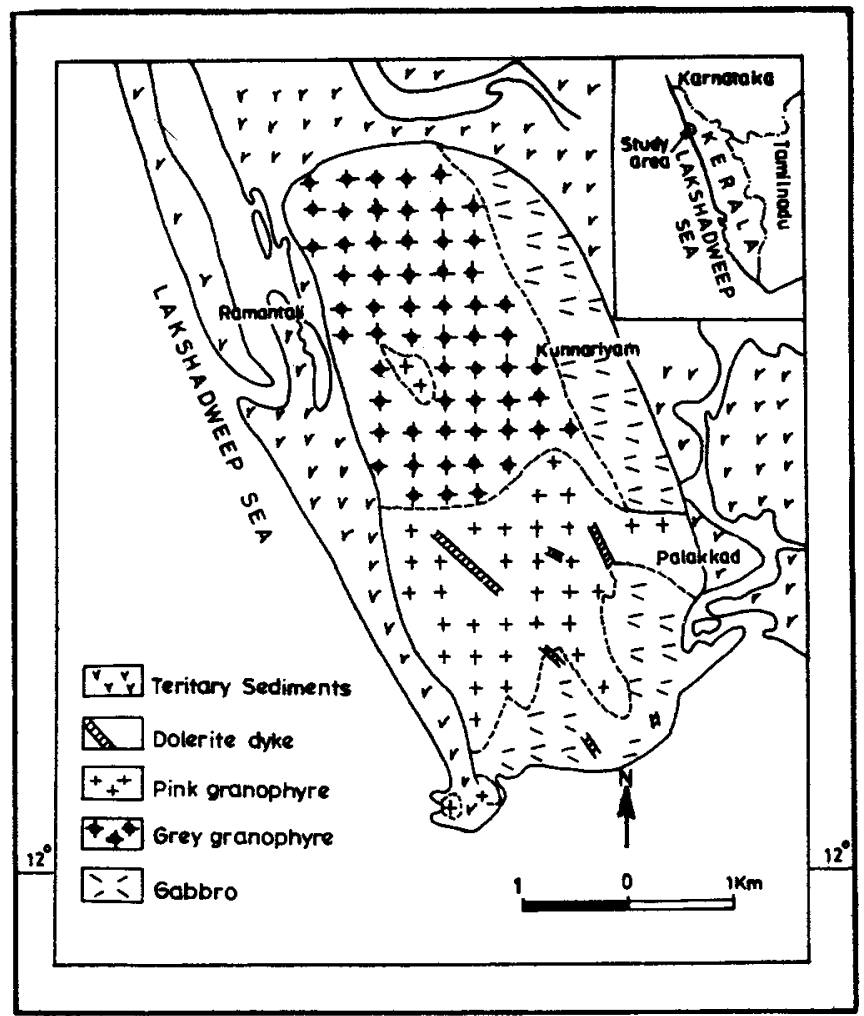

(b)

Figure 1. Geological maps of the Ezhimala area (after Nair and Vidyadharan 1982) (a) regional geology, (b) local geology. 
assigned to the granite and granophyres (Nair and Vidyadharan 1982) based on $\mathrm{Rb}-\mathrm{Sr}$ dating.

The granophyre stock at Ezhimala exhibits intrusive relationship with the associated gabbro body (figure $1 \mathrm{~b}$ ). The gabbro is locally traversed by veins of granophyre. Granophyres of both pink and grey varieties are noted and the pink variety grades into pink granites towards south of the complex. The associated gabbro locally incorporates anorthosite differentiates. A number of dolerite dykes cut across the lithotypes.

Studies at different outcrops show that both pink and grey varieties are generally massive, with an overall mineral assemblage of feldspar, quartz, biotite and magnetite. The grey variety has a predominance of mafic laths exhibiting irregular orientation. Both varieties occassionally show porphyritic texture with euhedral to subhedral feldspar megacrysts ranging up to $2.5 \times 1 \mathrm{~cm}$ in size.

\section{Mineralogy}

$\mathrm{K}$-feldspar, which is rarely microperthitic, forms the dominant mineral constituent and occurs both as megacrysts in porphyritic varieties and in the mesostasis. The megacrysts are generally orthoclase and locally show inversion to a more ordered state with faint microcline cross-hatching. Eventhough Nair and Vidyadharan (1982) observed plagioclase rims around the orthoclase megacrysts in a single quarry at Palakkad, the present study, based on a number of samples, did not substantiate this. $\mathrm{K}$-feldspar is also found in a hypidiomorphic granular fabric with quartz and minor plagioclase of albite-oligoclase range. The plagioclase laths of the grey granophyre are generally euhedral and show pronounced zoning with a more calcic core and a sodic margin indicative of the rapid change in composition of the fractionating magma. All the feldspars invariably show varying degree of sericitization or saussuritization.

Typical granophyric intergrowths of quartz and feldspar are noticed in some sections. Generally, the intergrowths are of cuneiform and radiating fringe types (Leighton 1954). The cuneiform type resembles graphic texture and in the radiating fringe type, micrographic intergrowth of quartz and feldspar radiate outward from anhedral grains of albitic plagioclase (figure 2). A minor insular variety, with islands and blebs of quartz set in a polygonal ground mass of alkali feldspar is also observed. In a few cases, fine-grained plumose types of textural intergrowths are also seen. In addition to the occurrence as a component in granophyric intergrowths, quartz is found also as a subhedral grains along with feldspars in normal granitic textures.

Augite showing varying degrees of resorption forms the dominant mafic constituent in the grey variety. Here biotite forms a minor accessory along with apatite and zircon. Euhedral biotite flakes with pleochroism and absorption as $\mathrm{X}=$ brownish yellow, $\mathrm{Y}=$ yellowish brown and $\mathrm{Z}=$ dark brown form the major mafic component in the pink variety. Locally, the biotite flakes show resorption to an aggregate of chlorite and magnetite. The magnetite grains are frequently bordered by a rim of epidote.

\section{Geochemistry}

Analytical results of major and trace elements in fifteen representative samples of the granite and granophyres of EIC are given in table 1 where the data are compared with those of similar rocks. Major elements were analysed by conventional wet methods and trace elements by atomic absorption spectrophotometer (Perkin-Elmer 4000). 

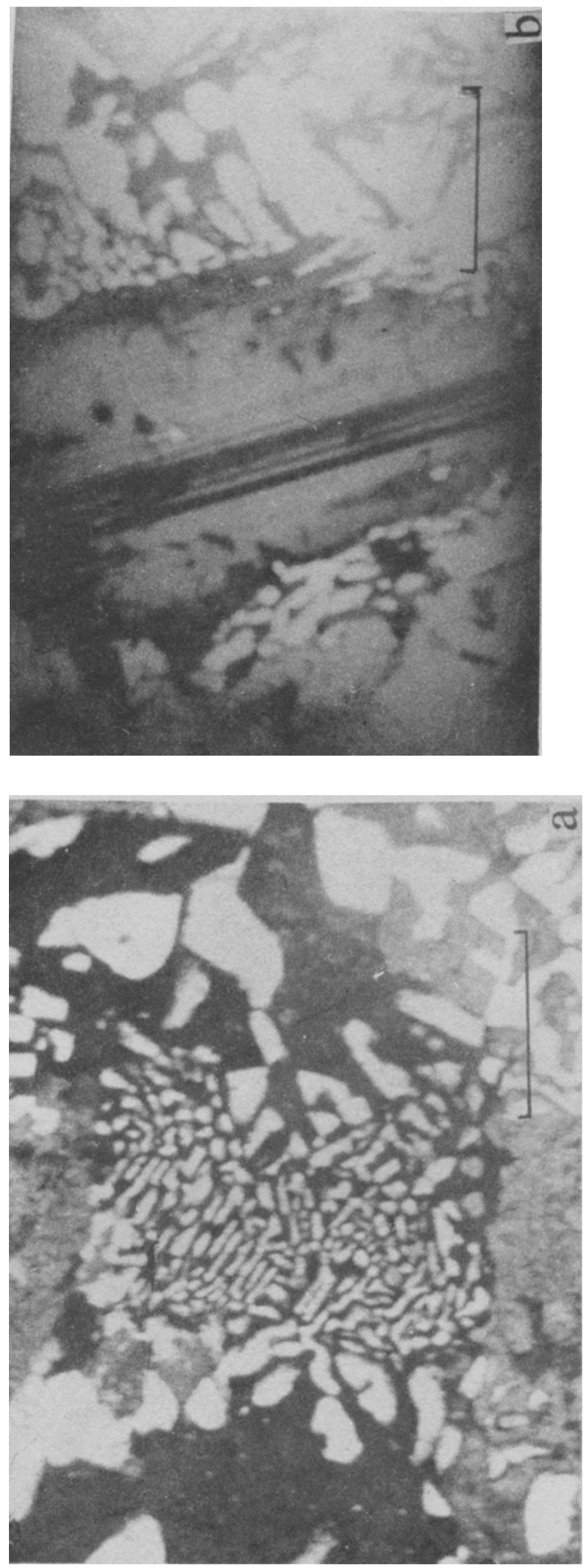

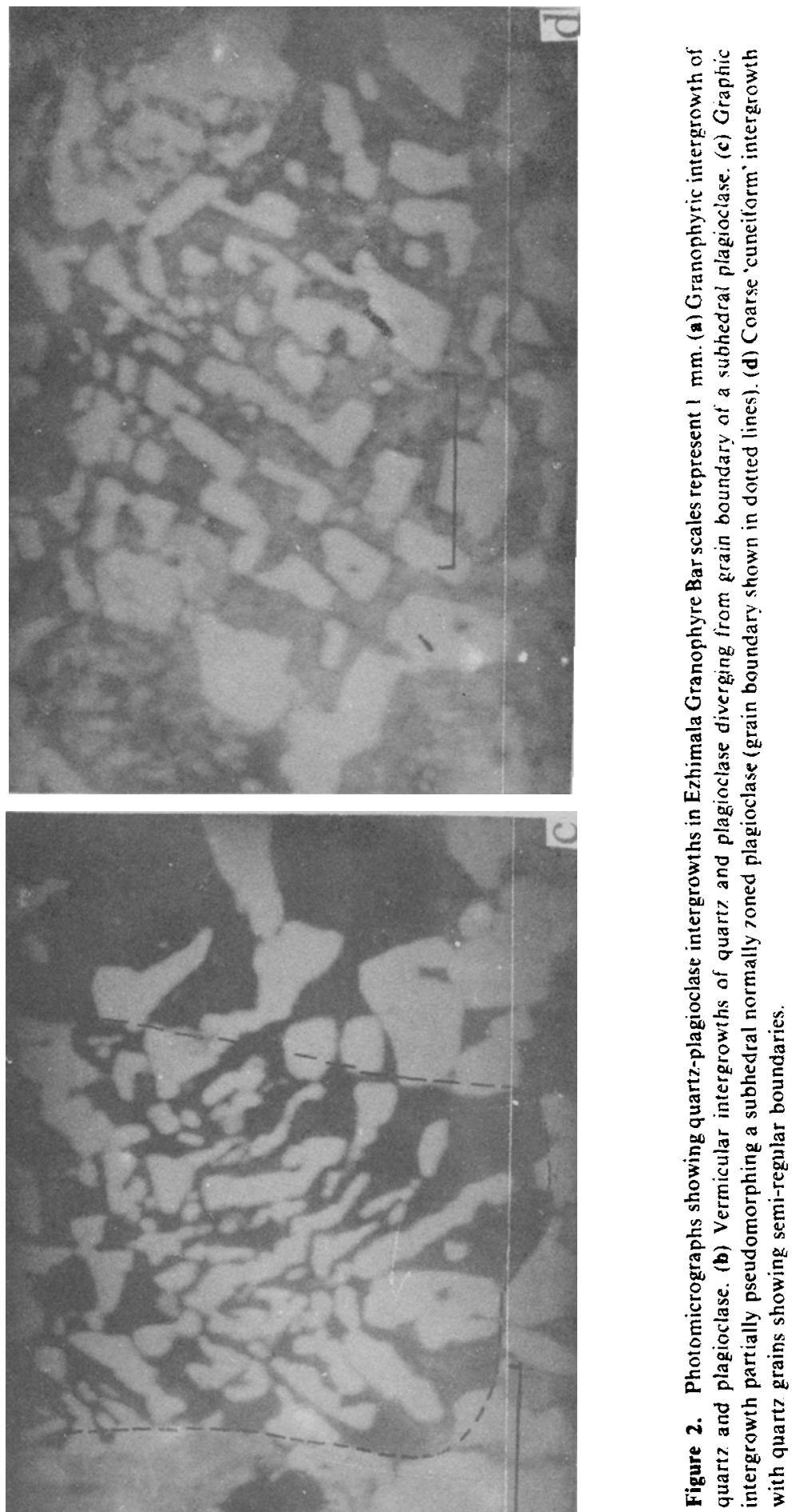
The mineralogical variation from grey to pink granophyre and granite is reflected in the $\mathrm{SiO}_{2}$ range of 64.57-75.81 with the mean value (71.21) falling intermediate between the Skaergaard granophyre and the Red Sea granophyre. With low $\mathrm{SiO}_{2}$ content, there is a correspoding increase in the $\mathrm{FeO}^{z}, \mathrm{MgO}$ and $\mathrm{CaO}$. The mean $\mathrm{Al}_{2} \mathrm{O}_{3}$, $\mathrm{Fe}_{2} \mathrm{O}_{3}, \mathrm{Na}_{2} \mathrm{O}$ and $\mathrm{K}_{2} \mathrm{O}$ values $(13.47,1.73,3.96$ and 2.98 respectively) are comparable with those of acid granophyre of Skaergaard (13.17, 1.56, 4.24 and 3.85 respectively).

Plots in $\mathrm{SiO}_{2}$ vs $\mathrm{K}_{2} \mathrm{O}$ diagram (Coleman and Peterman 1975) fall in the field of continental granophyre (figure 3). Eventhough variations in $\mathrm{K}_{2} \mathrm{O} / \mathrm{Na}_{2} \mathrm{O}$ and $\mathrm{K}_{2} \mathrm{O} / \mathrm{CaO}$ ratios indicate that the residual liquid varied through tonalitictrondhjemitic to granitic in composition, in an $A-F-M$ diagram (figure $4 a$ ) the plots closely follow a tholeiitic differentiation trend as defined by Barker and Arth (1976). This trend is identical to those observed in the case of continental granophyres (Coleman and Donato 1979) and is comparable with the trend of Skaergaard granophyre. Mutual relationship of alkalies is brought out in figure $4 \mathrm{~b}$ where $K$ and $\mathrm{Na}$ exhibit a more or less equal accumulation with respect to $\mathrm{Ca}$ and is different from the pronounced $\mathrm{Na}$-enrichment observed in tonalite-trondhjemite series. Alkali enrichment with respect to alumina towards the residual phase of fractionation is indicated by the occurrence of normative diopside (table 2 ) in some analyses.

Harker variation diagrams of the major element oxides (figure 5) show discernible magmatic trends. $\mathrm{Al}_{2} \mathrm{O}_{3}$ exhibit an overall depletion consistent with feldspar fractionation. $\mathrm{K}_{2} \mathrm{O}$ shows concentration whereas all the other oxides indicate moderate to sharp trends of depletion with progressive fractionation. The sharp decrease in $\mathrm{FeO}, \mathrm{MgO}, \mathrm{CaO}$ and $\mathrm{TiO}_{2}$ till the $\mathrm{SiO}_{2}$ level of 70 indicate continuous removal of mafic phases. However, there is only limited variation in $\mathrm{MgO}$ levels $(0.32-1.6)$ and the magnesium number $\left(\mathrm{Mg} / \mathrm{Mg}+\mathrm{Fe}^{t}\right)$ is less than 0.4.

The behaviour of trace elements is overall consistent with the empirical laws governed during magmatic differentiation (figure 6). Ba levels are initially rather high as $\mathrm{Ba}$ is not partitioned in the earlier phases of crystallization of the parent magma. As $\mathrm{K}$-bearing minerals (biotite and $\mathrm{K}$-feldspar) started crystallizing, $\mathrm{Ba}$ is accommodated resulting in a decreasing trend. The concentration of $\mathrm{Pb}$ with increasing differentiation index is also in agreement with the same. $\mathrm{Sr}$, which follows $\mathrm{Ca}$, shows a decreasing trend. $\mathrm{Cr}$ and $\mathrm{V}$ show depletion and $\mathrm{Cr} / \mathrm{V}$ ratio fall with fractionation. The initial higher levels of $\mathrm{Ni}, \mathrm{Cu}$ and $\mathrm{Zn}$ with sudden drop followed by consistent levels and absence of significant variations imply that crystallization of pyroxenes continued till the differentiation index value of 18 . Li shows a steady concentration.

\section{Discussion}

The major element levels in the present case correspond to a tonalitic-trondhjemitic to granitic composition of the residual magma. Crystallization of such a final residuum of a parent basaltic magma would lead to a eutectic mixture of quartz and feldspar which can either form normal granites or granophyres depending on the $\mathrm{P}-\mathrm{T}$ conditions. The spatial and genetic association of rocks with granitic and granophyric textures imply a sudden change in the $P-T$ regimes during the crystallization of the residual fraction. The typical occurrences of granophyric intergrowths indicate rapid simultaneous late-stage growth of quartz. and feldspar under cotectic conditions (Cerny 1971). The irregular blebs of sodic feldspar in optical continuity with the 


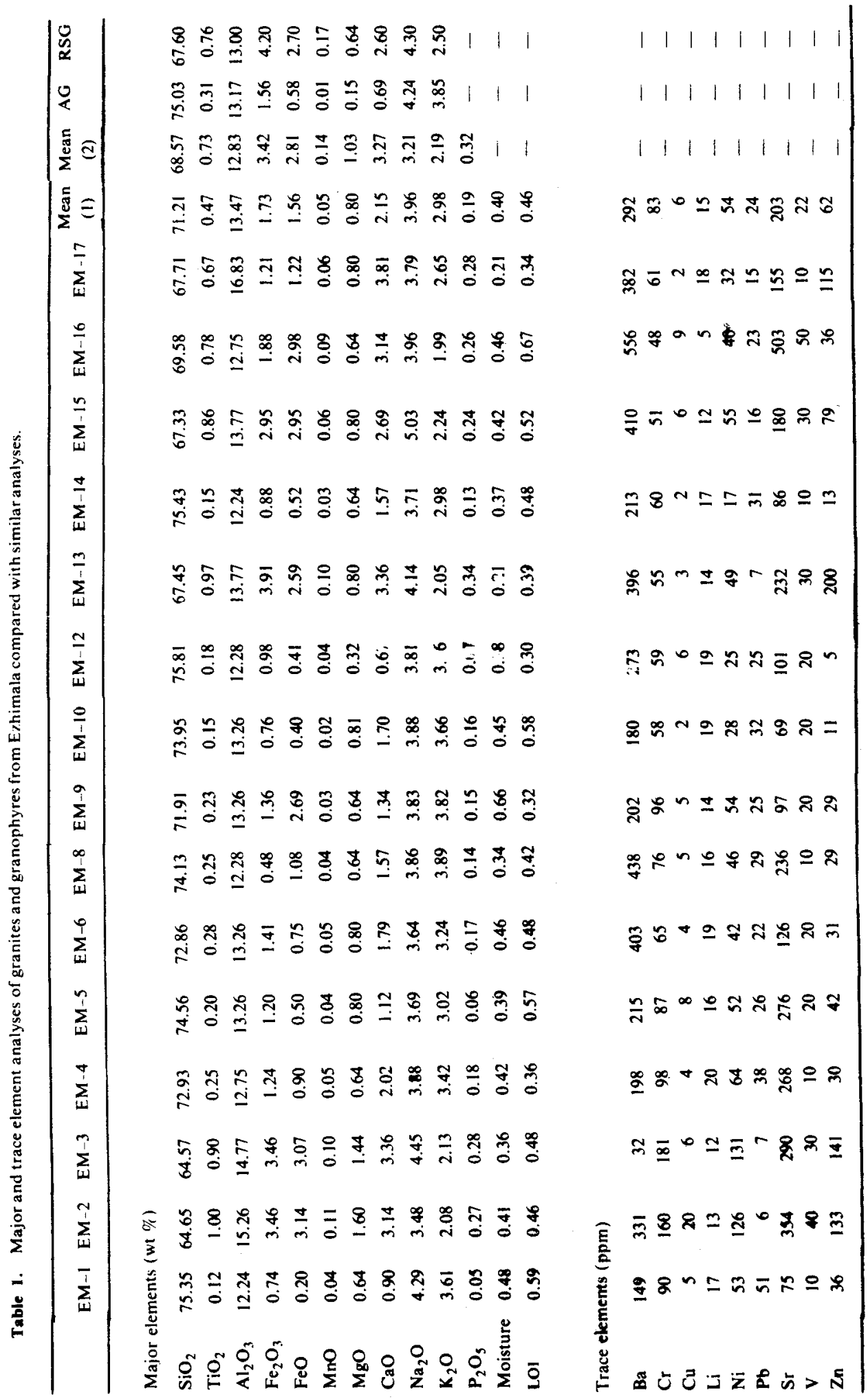

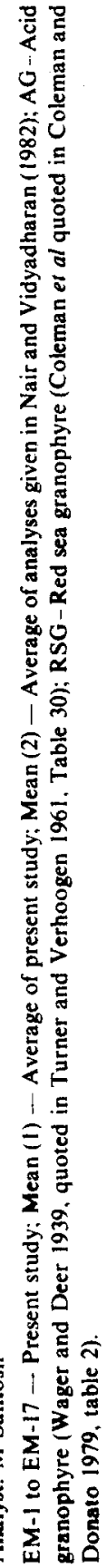




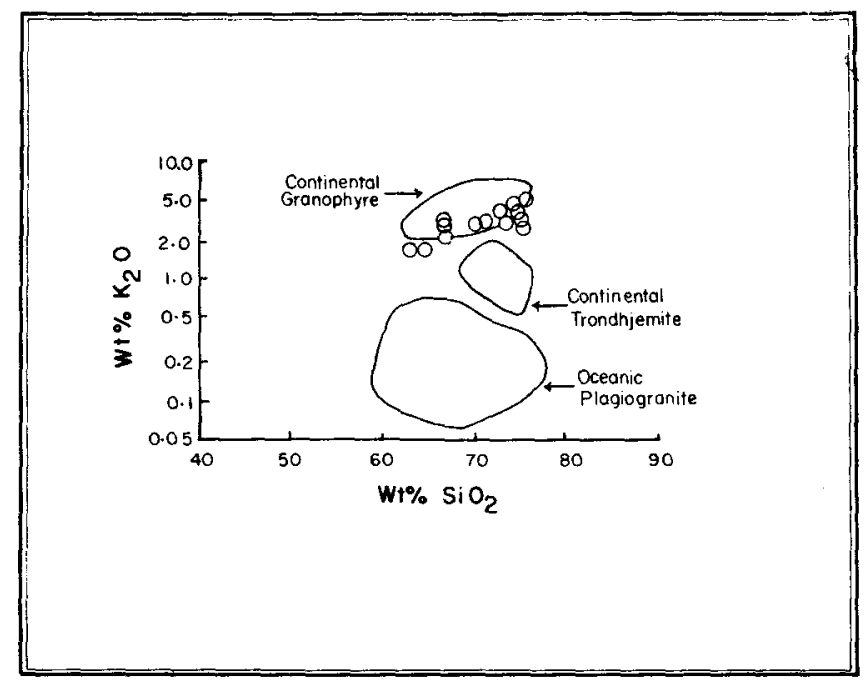

Figure 3. $\mathrm{SiO}_{2}$ vs $\mathrm{K}_{2} \mathrm{O}$ plots. The field boundaries are after Coleman and Peterman (1975).

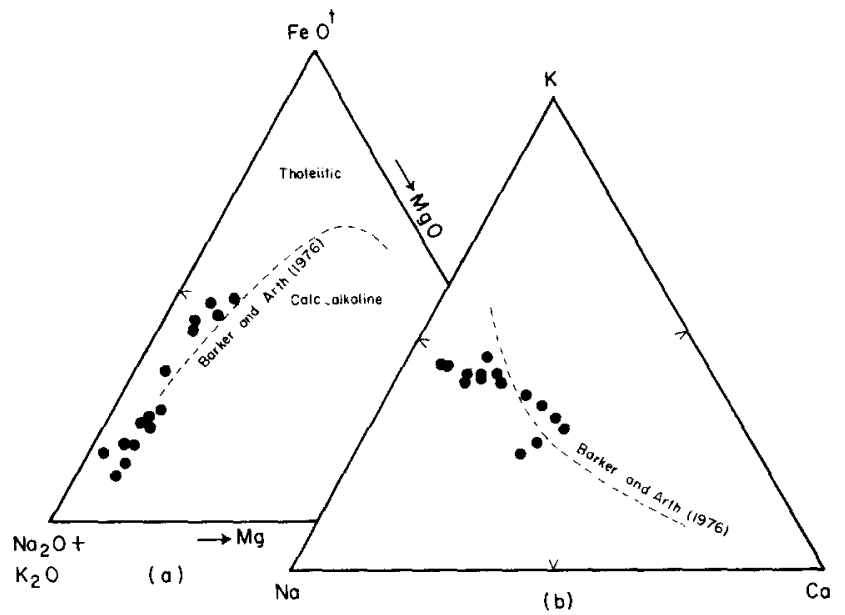

Figure 4. (a) A-F-M plots showing alkali enrichment trend, (b) $\mathrm{K}-\mathrm{Na}-\mathrm{Ca}$ plots. The boundary lines are after Barker and Arth (1976).

normally zoned plagioclase and the vermicular blebs of quartz and plagioclase making up much of the mesostasis between the plagioclase grains imply a late-stage supercooling of the liquid (Dunham 1968) brought about by a reduction of pressure below that which yields a normal granitic texture (Parsons 1972).

Variations in granophyric intergrowths in a single intrusive (Barker 1970) are conceived as a scale of the rate of cooling. From the bow-tie shaped plumose texture, which was experimentally produced by Lofgren $(1971)$ at $700^{\circ} \mathrm{C}$, to the coarse cuneiform intergrowth indicate a rapid lowering of temperature and pressure brought about by the high level emplacement of the granophyres, probably lineamentcontrolled. The presence of vugs/druses in the upper levels of the granophyre substan- 


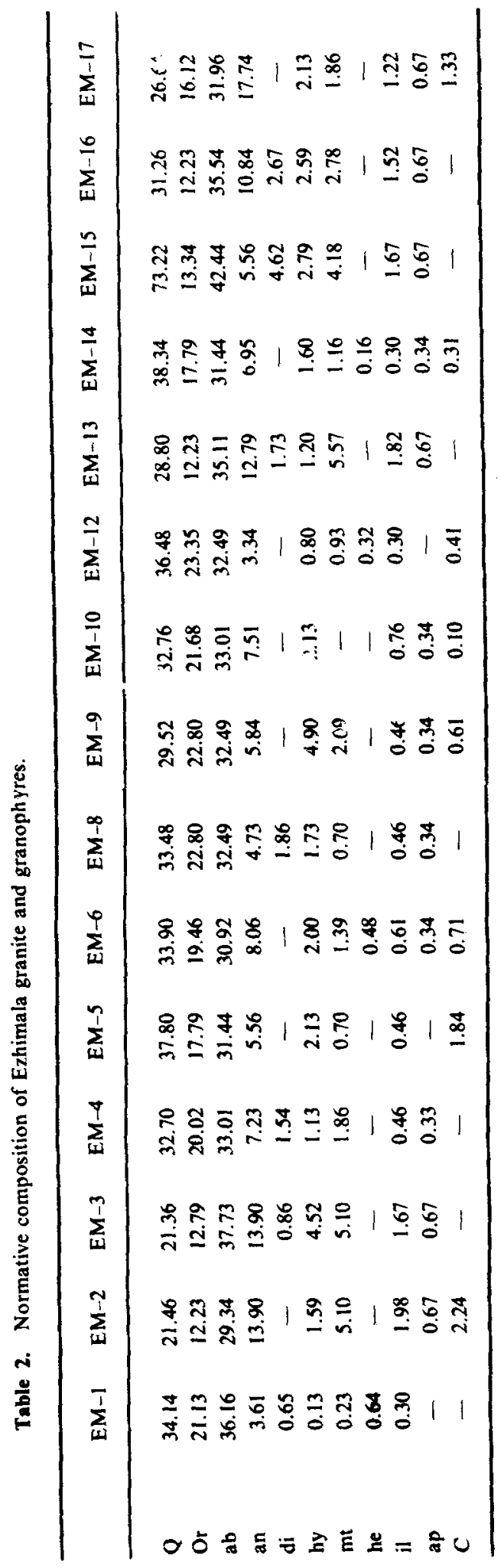



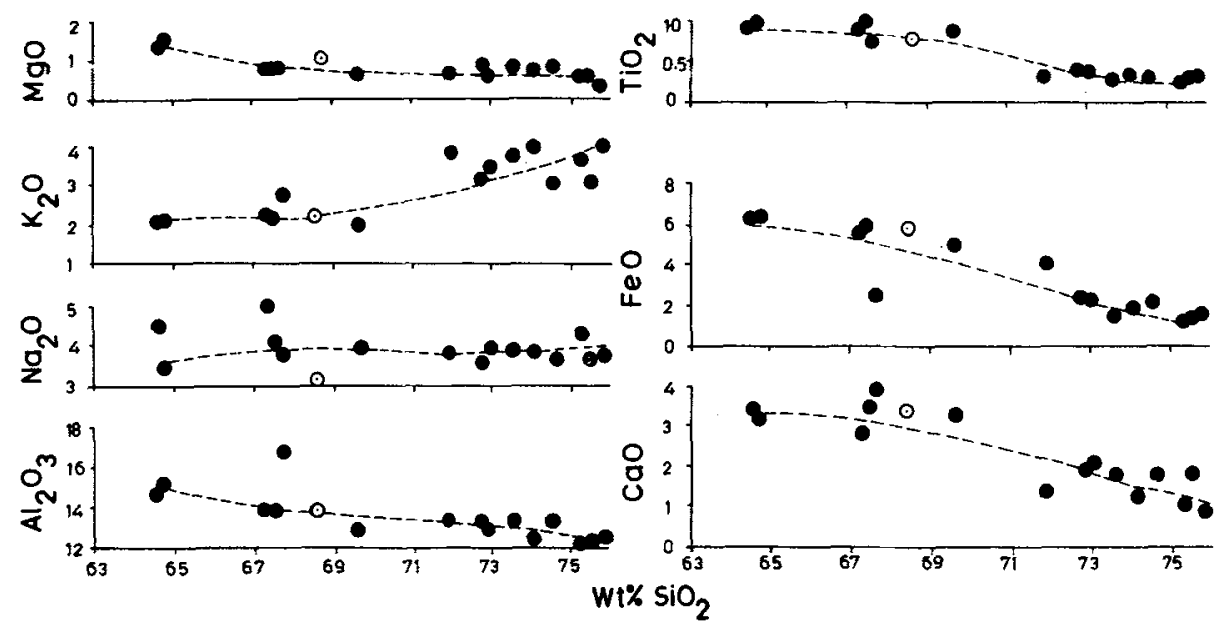

Figure 5. Harker variation diagrams of major elements in fifteen representative samples of the granite and granophyres of Ezhimala. The open circles represent average of values presented in Nair and Vidyadharan 1982 (table 1).
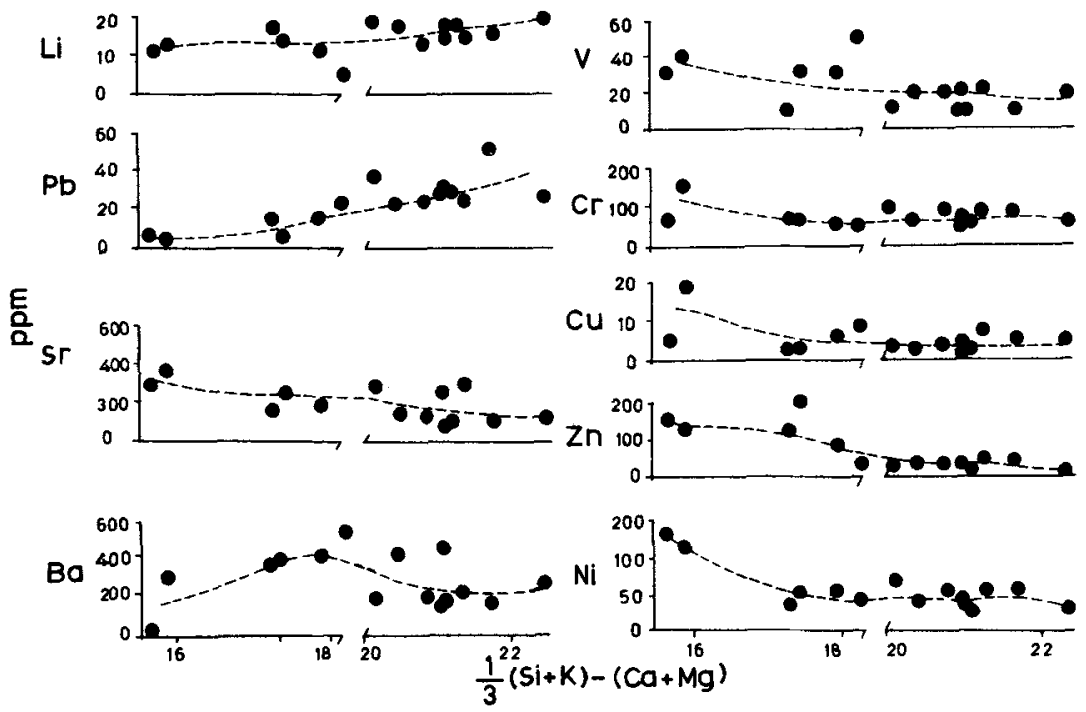

Figure 6. Trace element variation. 


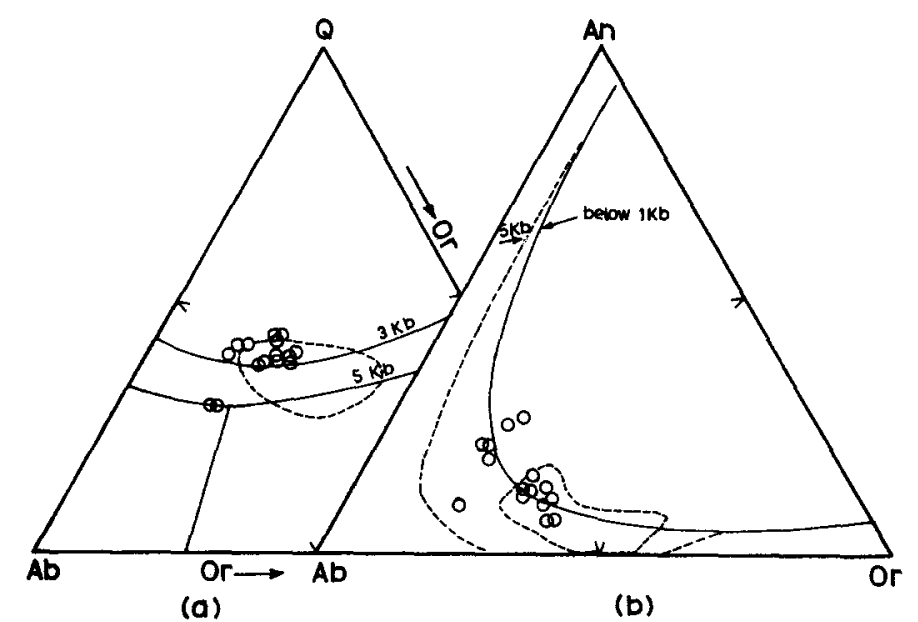

Figure 7. (a) Q-Ab-Or plots (after Tuttle and Bowen 1958). (b) Normative feldspar plots. The Plagioclase boundaries are after Glikson and Sheraton (1972). Dotted line represents field of granophyres as compiled by Barker (1970).

tiates the view that the rock was emplaced at high level and near to the surface (Varadan et al 1976). The normative Q-Ab-Or plots (figure 7a) cluster towards the granite minimum at $3 \mathrm{~kb}$. Plots in a feldspar ternary (figure $7 \mathrm{~b}$ ) also fall in the low pressure field, consistent with similar observations of Coleman and Donato (1979). In both the diagrams, the plots lie within or close to the field of granophyres as compiled by Barker (1970).

The sericitization and saussuritization of the feldspars with associated alteration products like epidote imply the activity of post-inıgmatic hydrothermals (Marmo 1971) generated here probably during the later emplacement of the mafic dykes. Such hydrothermal alterations are observed elsewhere also (Coleman and Donato 1979).

With the association of lithotypes showing compositional variation from anorthosite through gabbro to granite and granophyre the EIC represents a complete differentiation sequence resulting from strong fractional crystallization and crystal cumulation of a parent basaltic magma which followed a general tholeiitic differentiation trend with no significant crustal participation as implied by the low initial ${ }^{87} \mathrm{Sr} /{ }^{86} \mathrm{Sr}$ ratios for the granite and granophyres obtained from the isochron plot (Nair and Vidyadharan 1982). Separation of early mafic phases initiated precipitation of intercumulus plagioclase. Flotation and seggregation of discrete plagioclase led to the cumulus anorthosite (Goode 1977). With the enrichment of silica and alkalies, the ultimate fraction attained tonalitic-trondhjemitic to granitic composition. Further fractionation was largely controlled by $\mathrm{K}$-feldspar as indicated by the depletion of $\mathbf{B a}$ (Hanson 1978).

Spatial associations of acid intrusives with regional lineaments representing probable rift-settings a re typical in Kerala and are recently deriving much attention. Even though no geophysical data are available, the Bavali lineament is considered to be a major rift-zone as inferred from the petrochemical characters of the perpotassic pluton of Peralimala which occur along this lineament (Nair and Santosh 1983). Occurrence of the EIC close to the rifted continental margin and distribution of its litho-types along the Bavali lineament emphasise a rift-controlled magmatism in this part of the Indian shield during the Late-Precambrian times. 


\section{Acknowledgements}

The present study forms part of the CESS project. The authors are grateful to Prof. C Karunakaran for facilities. Ms Ansom Mathew is thanked for her assistance in chemical analyses. The authors are thankful to the two reviewers for valuable suggestions.

\section{References}

Barker D S 1970 Bull. Geol. Soc. Am. 813339

Barker F and Arth J G 1976 Geology 4596

Cerny P 1971 Contr. Mineral. Petrol. 30343

Coleman R G and Donato M M 1979 in Developments in petrology (ed.) F Barker (Amsterdam : Elsevier) 6 149

Coleman R G and Peterman Z E 1975 J. Geophys. Res. 801099

Dunham A C 1968 Q. J. Geol. Soc. London 123327

Glikson A Y and Sheraton J W 1972 Earth Planet. Sci. Lett. 17227

Goode A D T 1977 Earth Planet. Sci. Lett. 34375

Hanson G N 1978 Earth Planet. Sci. Lett. 3826

Leighton M W 1954 Bull. Geol. Soc. Am. 65401

Lofgren G 1971 Bull. Geol. Soc. Am. 82111

Marmo V 1971 Granite petrology and the granite problem (Amsterdam: Elsevier) p. 244

Nair M M and Vidvadharan.K T 1982 J. Geol. Soc. India 2346

Nair N G K and Santosh M $1983 \mathrm{~J}$. Geol. Soc. India (in press)

Parsons I 1972 Medd. om Gronland 19573

Santosh M and Nair N G K 1983 J. Geol. Soc. India 24291

Turner F J and Verhoogen J 1961 Igneous and metamorphic petrolog.y (New York: McGraw Hill) 694

Tuttle O F and Bowen N L 1958 Geol. Soc. Am. Mem. 741

Varadan G N and Venkataramana B 1976 Ind. Minerals 3096

Varadan G N, Venkataramana B and Viswanathan TV 1976 Simp. Paleovolcanicity, associated tectonism and metallogeny in India (Ind. Acad. Geosciences. Hyderabad). p. 31 